\title{
Richard Wagner's Parsifal at Bayreuth and 21st Century in the World: From the Viewpoint "Mitleid (Compassion)" using Interdisciplinary Studies
}

Takao Kawanishi

\author{
Doctoral Course, Kwansei Gakuin University, Japan
}

E-mail: takao.kawanishi@kwansei.ac.jp

Doi:10.5901/ajis.2013.v2n9p361

\begin{abstract}
Parsifal(1882-) also called Bühnenweihfestspiel is known as Richard Wagner's Opera concerning about Legend of Holy Grail's Knight in Europe, and that Parsifal had become the final work of Wagner's life and been completed at Bayreuth in Germany at last and played on for the first time and decided Bayreuther Festspielhaus as the only place by his testiment at that time. The aforementioned, I will point out that Bayreuth had historically the Legend of Holy Grail's Knight in Europe to draw Wagner's Parsifal to Land of Bayreuth, especially the time of Bayreuther Markgraf G. Wilhelm, and next Markgraf Friedlich and Markgräfin Wilhelmine in 18th century. Beside, after the Second World War, this Parsifal with sprit of Mitleid(Compasstion) is alive and evolves even nowadays. And I state by using Interdisciplinary Studies such as history, literature, religion, geography and crossculture or mysticism that these Essences of Parsifal are not Germanic Hero like propaganda of Nazis era but mutual understanding, sympathy, and cooperation such as Mitleid on human being around the world.
\end{abstract}

Keywords: Wagner, Parsifal, Bayreuth, Mitleid(compassion), Markgraf G. Wilhelm, Markgraf Friedlich and Markgräfin Wilhelmine

\section{Introduction}

German Composer Richard Wagner (1813-83) who stayed at Bayreuth in Germany at the late of his life time, built opera house for his works of opera and at last completed Parsifal called "Festival opera sacred stage" (Bühnenweihfestspiel).

This thesis mentions about intimate relevancy between these Legends of Holy Grail's Knight in Europe that is main theme of Parsifal, and Bayreuth City using inderdisciplinary approaches, such as historical, geographic, religious, crosscultural veiwpoints.

Bayreuth that was founded at German east frontier in the Era acadimical called "12 $2^{\text {th }}$ Century Renaissance" bloomed culture of European middle-age, was city used as Crusader's important routes by intimate relevancy of Bamberg bishopric, besides crossed Idea and Culture between European Christianity and Arabic Islam world. Therefore, surrounding area of Bayreuth had Legend's world of Holy Grail's Knight described Perceval ou le Conte du Graal (Perceval) by C.Troyes(1140- end of 12c.), and Parzival by W.Eschenbach(1160or80-approx. 1220).

As far as prior research about relationship between these 3 works(Perceval, Parzival and Parsifal) and Bayreuth City, it remain a few view point of literature, thus, historical and geographical or cultural-exchange approach is nothing.

Moreover regarding between Perceval and Parzival in $12^{\text {th }}$ Century Renaissance do not enough about these approaches, Holy Grail's Knight of 3 works was consecrated as Hero and Savior to unclearly remain and not to strictly research on historical meaning of these works. Therefore, by Nazis in the first half of $20^{\text {th }}$ century, Legends of Holy Grail's Knight that was altered as Savior of German national was made use of Nazis propaganda to justify of German superiority and supremacy in the world.

However, Parsifal in Bayreuth that reached the state of mind"Mitleid(compassion)" in Wagner's later years and last work in his life, came out with new sense of values not like Nazis propaganda. Wagner deeply understood those 2 works of $12-13^{\text {th }}$ century, and guides to us in $21^{\text {th }}$ century.

I wish to access and reach in this thesis to the real idea and spirit of Legend of Holy Grail's Knight in Europe succeeded to Wagner's Parsifal in Bayreuth using those above inderdisciplinary approaches.

\section{Richard Wagner and Legend of Holy Grail's Knight}

\subsection{From Lohengrin to Parsifal}


Wagner's first time access to Legend of Holy Grail's Knight was Parzival by W.Eschenbach.

In 1845 , he began to read this story in Bohemia to get medical treatment in his time of Dresden's courtly Opera house conductor.

At first, Wagner tried to produce Opera Lohengrin from theme of son of Parsifal as Legend of Holy Grail's Knight. Lohengrin was first performed in 1850 at Weimar by Franz Liszt(1811-86) who was very strong supporter of him.

In Lohengrin's Story, the leading role is Lohengrin as Legend of Holy Grail's Knight who save the principality and this princess. Afterward, in Parsifal's story, father of Lohengrin appears as great savior of world. This meaning points that both Opera story is closely related like one story and Wagner was continuing to research about Legend of Holy Grail's Knight to complete as opera-performance.

Also, it must pay attention that Lohengrin played first in Weimar where was at center of Germanic Art and culture at that time. After this performance, Wagner "advanced " to Bayreuth, this meaning pointed that the center of these moved from Weimar to Bayreuth by Wagner's settle in Bayreuth(1872-), opening of Bayreuth Festival(1876-), and great success of Parsifal first performance(1882) of Legend of Holy Grail's Knight in Bayreuth at the same time of unified nation of Germany.

And also Liszt who played active in Weimar, had so interesting about Bayreuth Festival, was in Bayreuth as final place and had his grave in it. Even after Wagner's death, the world establishments such as artist, politician, ideologist, success of business, the upper classes etc, came to see the festival, they talked about modern theory, or aesthetics, philosophy going through Wagner's Arts symbolized unification of Germany at that time. In the end of $19^{\text {th }}$ century, Bayreuth in stead of Weimar became in the center of European fashion and social contact.

The "Inspiration" making of Parsifal by Wagner was said at "St.Friday" in April 1857. In that time, Wagner used title Parzival same as W.Eschenbach. Wagner strengthened his determination to inform not to misunderstand this deeply and difficult this contents, and to arrange main stories in 3 stages. He kept in mind as his calling to revive the Legend of Holy Grail's Knight, and continued to study about this Legend in various fields.

Moreover, Wagner sought for origin of Legend of Holy Grail's Knight outside of Christian area as the East like Islam region and another culture area of Asia. For example, he said "Holy Grail is miracle stone, This reason become clear by Arabic and Moore people(Islam) from Spain", or "Moore people worships miracle stone at Kaaba temple in Mecca" (1859)

This Wagner's interest about Islamic world was so profound. It is clear that in his first half of $19^{\text {th }}$ century he had already written Opera's drafts of Arabic story. They had been named by him "Happy bear's family" (1837-39), and "Woman in Persia" (1841-43).

I state that these profound interests of him is not influenced by Schopenhauer(1788-1860)'s philosophy and literatures about Eastern religion and culture for the reason of Wagner's failure of Dresden Revolution that it was said as usual.

Also, Wagner was influenced by Hafez as known Persian famous poet in the Middle Ages, he must be taken notice by such profound thoughts and adoration to the East as well as C.Troyes and W.Eschenbach.

Moreover, Wagner changed title from Parzival to Parsifal meaning of Pure-fool as Arabic phonetic (exactly Persia phonetic) adopting theory of J.Görres(1776-1848) when the second draft of Parzival completed in 1877.

Görres insisted in his "Lohengrin, ein altteutsches Gedicht"(1813) that Parsifal is correct name because original root of Parzival by W.Eschenbach is not from Europe but East world like Arabia. Also, Wagner accepted the theory of Görres because Wagner thought that Christianity was build under the influence of Asian religions.

In Parsifal, Wagner invites his audience to Holy Grail Castle by Comprehensive Art such as his matured music expression, special sound effect of Bayreuth festival hall(festspielhaus), and stage performance, using motif of oracle in Parsifal "worried together, and realize... wait for the man like Pure-Fool(=Parsi-Fal), because God chose him."

In the next paragraph, it explains about more ties of Parsifal and the festspielhaus in Bayreuth.

\subsection{Parsifal as Festival opera sacred stage and Bayreuth}

Parsifal's final draft was made the next year of 1876 when the festspielhaus constructed. The full score completed in 1882, it was first staged in Bayreuth. About 6 month after the success year, Wagner passed away. Thus, he spent and tried to work on 37 years in the latter half of his life making Opera about Legend of Holy Grail's Knight from first draft of Lohengrin (1845) until the first performance of Parsifal at the festspielhaus in Bayreuth.

This exceeded time than the making 4 days opera Der Ring des Nibelungen as known Ring that it was said Wagner spent more long time when he spent 26 years from its first draft (1848) until first performance (1874). 
Wagner tried to give Parsifal entirely different meaning with ordinary opera that play a performance changing theater each place. At first, as mentioned above, Wagner named Parsifal as Festival opera sacred stage (Bühnenweihfestspiel), He forbade to play it except festspielhaus in Bayreuth.

This Wagner's order(will) disregarded of the common sense of opera's management rising its name and sales by tour performance to move another theater. After Wagner's death, this his will kept in 30 years until Parsifal's copyright expired at 1913.

In addition, Parsifal was forbidden even curtain call to watch the evaluation of its performance, thus, Parsifal in Bayreuth looked like religious and sacred ceremony.

About the Wagner's intention, it will become clear by the following letter that he sent in 1880 to Bayern King Ludwig II.

"I want only my last and most divine this opera not to be followed the same fate like another opera, stage of Parsifal must purify, it can not realize except Bayreuth festspeilhaus, this is my only wish"

This letter as if he already knew his end of life time, informs his will in last time expected for "Parsifal in Bayreuth".

Parsifal got good impression and success in premier stage, but received argument against possession of the only performance in Bayreuth to be played in and outside Germany.

However, playing direction by Wagner about Parsifal's Prelude was "not dramatic, must be origin (fundamental)", this Parsifal was really his will involving his final state to reach in Bayreuth. And this was spiritual work deep-rooted in this land history, and that was Legend of Holy Grail's Knight succeeding long time in Bayreuth as following.

In next chapter, it go back to time of 12th Century Renaissance to research about relationship between foundation of Bayreuth and original story of Legend of Holy Grail's Knight.

\section{Foundation of Bayreuth and House of Andechs Meranien -to the City of Legend of Holy Grail's Knight-}

The foundation year of Bayreuth is not clear, therefore, it was decided at 1194 when the name was written at the first time in the old document of Bamberg Bishop Otto II (1132-96).

About the meaning of "Bayreuth" was defined "reclaimed land by people of Bayern" by old theory such as Bayer (people of Bayern) and reuth (reclaimed land). Thus, it was thought that people of Bayern who lived in land of Bishopric Bamberg reclaimed land of Bayreuth and settled there.

However, in this time, House of Andechs Meranien ruled the land of Oberfranken and Bishopric Bamberg, and produced Bishop Otto II from this House. Therefore, it must think Bayreuth was new city for this House of Andechs Meranien or founded as city by the new ideal and concept sought this House around Bamberg.

House of Andechs Meranien that root of Bayern, however, by means of marriage politics, occupied many important route, kept trading routes from Kingdom of Jerusalem to Bishopric Bamberg as "New Rome" cooperating with Crusader Knights to protect these route and settlement base city including Bayreuth. In other words, Bayreuth was made as not reclaimed land for farming but trading basement city from east to Bamberg.

Moreover, House of Andechs Meranien had close relation Perceval and Parzival as Legend of Holy Grail's Knight, so it can be surmised that the ideal of Bayreuth's foundation was influenced with these Legends.

Therefore, when Bayreuth appeared first time, in story of Perceval which was brought by House of Andechs Meranien from France to this Oberfranken, it is highly core of scene that Perceval saw Holy Grail and Holy Speer when he was permitted to enter Holy Grail Castle. In this scene of Perceval, it was written the suggestion about foundation of Bayreuth, following.

"At that time, top of the tower(Holy Grail Castle) was appeared, Until Barut it can not see so beautiful tower". -Au château du Graal,3050-3052-.

This Barut means in now Beirut capital of Lebanon, but in $12^{\text {th }}$ century, The around Beirut was built many Towers by Crusader, and Beirut was important trading and military cross point of Europe and Middle East access to Jerusalem. This city prospered international Cross Culture to come and go for trade, battle, pilgrimage and travel by various religious people such as Muslim, Jewish, Christian, Buddhist, Hindi, etc.

House of Andechs Meranien also traded with Middle East using their sea or land routes. 
Thus, It can be said that Bayreuth was made as new city had role of "new Barut(Beirut) " like the land of the Legend Holy Grail's Knight connecting between Bamberg and another world region such as Middle East, Slav, Asia, and Africa.

In 1199, the 5 years after from Bayreuth's "foundation", Bayreuth that was called "villa" meaning residence of wealthy person was written "Beirrut" very similar to Beirut in Lebanon.

Also Beirut in Middle East ruled by Knights Templer at that time, it suggests this House traded widely between these "Two" Beirut.These points connected that, following in $18^{\text {th }}$ century of Bayreuth, raised again Legend of Holy Grail's Knight and historical relation between Beirut and Bayreuth, strengthened mysticism of Bayreuth as following.

In addition, City Church in Bayreuth put on Mary Magdalene as Patron Saint, these believe in holy woman, especially in Bishopric Bamberg as Catholic stronghold, was considered as paganism.

Therefore, the first time of settlers in Bayreuth, above mentioned, were different with settlement only for farming from people of Bishopric Bamberg. They were relative of House of Andechs Meranien with deeply believe to holy woman, and Knights Templer, Teutonic Knights connecting this House as same believer such as St. Maria, St. Anna or the St. Mary Magdalene. So, it was strengthened such meanings and view points that Bayreuth made to stay them in suburb of Bamberg.

However, Bayreuth after extinction of House of Andechs Meranien in middle of $13^{\text {th }}$ century, jointed under Count of Nürnberg Castle was erased superficially relation of this House.On the other hand, the spiritual tradition of House of Andechs Meranien and Legend of Holy Grail's Knight was taken over in Bayreuth handed down from generation to generation. So, finally in the $18^{\text {th }}$ century, it revived Legend of Holy Grail's Knight by Markgraf in Bayreuth.

\section{Legend of Holy Grail's Knight in Bayreuth}

\subsection{Markgraf Georg Wilhelm and "Parsifal"}

Legend of Holy Grail's Knight appeared in the time of foundation of Bayreuth in $12^{\text {th }}$ century was revived by Georg Wilhelm, Markgraf von Brandenburg-Bayreuth (1678-1726) and was recreated in the ideal city of St.Georgen in Bayreuth by him.

At first, it is survey of the life of G.Wilhelm who was born in Bayreuth as successor of bravery father of Markgraf Christian Ernst(1644-1712) was the dreamer concerning about Legend of Holy Grail's Knight and Mysticism of Bayreuth History was like "pure fool" (equal to Parsifal) boy who played sometimes around the lake Brandenburger near the city as following.

And in younger days, G. Wilhelm went for the diplomatic trip as successor of Markgraf (also it was said Grand Tour) to England in the end of $17^{\text {th }}$ century. In England, It is said he was fascinated by St.Georg as Legend of Dragon Killer, and Legend of King Arthur being root of Legend of Holy Grail's Knight, and that G. Wilhelm was very interesting about the Knight of the Garter as real ruling system in England having root of these Legends.

After he came back to Bayreuth, he was symbolized himself as incarnation of St.Georg founded Knights called "Knights of allegiance (Ritterorden der Aufrichtigkeit)" to guard Markgraf Bayreuth.

And he became Master of the Knights himself made Castle of Knights as Holy Grail Castle, and Church of Knights as center of Holy Grail's believe in his ideal city of St.Georgen (1705) around the lake Brandenburger existed at that time.

However, when G.Wilhelm went togather his army to west-border of Germany(Holy Roman Empire) to defend against invasion French army of King Louis XIV"the Sun king" (1638-1715), he was injured seriously and had after-effect in his life by shooting of enemy at Landau.

After this injury, G.Wilhelm who succeeded title of Markgraf devoted himself to defend and prosper of land of Markgraf Bayreuth. He built opera theater and invited G.Telemann (1681-1767) as regular conductor who was one of the best composers at that time in Europe. So, it can be said that Markgraf G.Wilhelm is the founder of Festival History at Bayreuth reached in now.

And, such life of Markgraf G.Wilhelm and St.Georgen has vivid recollections of Legend of Holy Grail's Knight such as Perceval and Parzival brought to Bayreuth in $12^{\text {th }}$ century.

It suggests to revive Legend of Holy Grail's Knight in Bayreuth that the life of G.Wilhelm wished development of his land and relief himself from holy land around lake such as injured King protected by Knights.

After that, Bayreuth Festival hall (Festspielhaus) of Wagner was built beside this St.Georgen. Thus, it can said to connect "Parsifal in Bayreuth" in the future.

In the next sentence, it refers about the mysticism of Europe that G.Wilhelm brought to Bayreuth. 


\subsection{Holy Grail's Knight of Bayreuth and European mysticism}

In the era of Markgraf G.Wilhelm, Bayreuth got higher mysticism of Europe such as Legend of St.Georg, King Arthur, and Legend of Holy Grail's Knight, moreover ideology of Rose cross (Rosenkreuz) reach to Freemason in future.

With "Deification of G.Wilhelm", it was mentioned relation between Bayreuth and Beirut that origin of foundation of Bayreuth existed "Phoenician Bayretuh(Beirut)" in Lebanon where defeated Dragon such as Legend of St.Georg.

Moreover, official seal of city of St.Georgen at that time was engraved the scene that G.Wilhelm defeated Dragon. As the wealth and art culture of this Markgraf city prospered, It began to emphasis originality of Bayreuth was as city succeeding Legend of Holy Grail's Knight by House of Andechs Meranien not position as brother city of Nürnberg.

G.Wilhelm who celebrated Day of St.George on April 23 at Ordens castle(Ordensschloss) in St.Georgen not only performed Opera on the lake named "Brandenburger Sea" by him using Battleships of Markgraf but also officially commend his Knight with order of Loyalty(Ordens de la Sincérité) founded himself.

This decoration was continued half of century after G.Wilhelm's death. The Crest of recipients of Order was decorated in chancel of Ordens Church (Ordenskirche).

This Ordens Church that exactly was Holy Grail for G.Wilhelm was dedicated to His mother Markgrafin Sophie (1642-1702) named at first Sophie Church(1705). When G.Wilhelm was succeeded Markgraf in Brandenburg-Bayreuth, renamed Ordenskirche, and placed emotional mainstay of Knights Ordens de la Sincérité as Holy Grail's Knights in Bayreuth.

Moreover, beside of this Church, Huge one steeple was constructed in 1718. Exactly like denouement of Parsifal's finale, by the pair of Holy Speer and Holy Grail, complete salvation of the world. This inside large bell named "Bell of Knight", with sound of this bell, scene of entering such as Parsifal and Holy Grail's Knights into Holy Grail's Castle, it "coincide" variously with after Parsifal's scenes.

This ideal of Ordenskirche existed at St.Georg Church of Windsor Castle in England where decorated Crests of Knight Order of the Garter in this chancel. Also because this castle is headquarter of Knights Garter, It is possible to say that G.Wilhelm reign his land of Bayreuth using the system of Knights Garter relating with Legend of King Arthur.

On the other hand, G.Wilhelm brought to Bayreuth new Ideals and ideology such as Rose-cross (Rosenkreuz) that was one of mysticism in Europe at that time.

This Ideal that included various religious God and advanced science at that time to reach to beginning of philosophy of the Enlightenment in $18^{\text {th }}$ century from wisdom of ancient Europe, to Judaism and Islam, also was received by Bayreuth citizens.

This Bayreuth City make progress keeping tolerance policy to accept theory, culture, and advanced skill of people called heresy or minority in contrast Bamberg and Nürnberg failed management of city to repeat persecution of Judaism's people and the women called witch hunting at 30 years War in $17^{\text {th }}$ century.

In spite of such the times of religious intolerance, Bayreuth accepted such as Huguenot persecuted in his own country is very characteristic to weather through the times by enlightening policy.

This ideal of Rosenkreuz was succeeded after that by Bayreuth Markgraf Friedlich (1711-63) and his wife Markgräfin Wilhelmine (1709-58) who was elder sister of Friedlich the great. Afterwards, the Loge of ideal society of Freemason that systematically strengthen Rosenkreuz placed into the court of Markgraf in Bayreuth (1740).

Markgraf Friedlich who himself installed as the first grand master of this loge protected Freemason in this land, spread relation with them in another countries, for example, invited Voltaire(1694-1778) in Bayreuth who was known as idealist of enlightenment.

After that, it was said that Wagner who settled to Bayreuth tried to join membership of the outstanding Grand loge of Bayreuth at Germany in his time. In addition, Wagner's residence in Bayreuth named Wahnfried is next of the Grand Loge.

This Grand loge called secret ceremony of Eleusis (Eleusis zur Verschwiegenheit) believed in transmigration and return to the land of dead was broken up and confiscated by the first half of $20^{\text {th }}$ century by Nazis.

However, this loge revived after the World War II because of defeat of Nazis regime became German Freemason Museum, and had role as witness of German Freemason History.

Also, in this loge of Bayreuth many Jewish people existed. And beside of Markgraf theater in Bayreuth placed in synagogue. Thus by $18^{\text {th }}$ century, it can be thought that this Jews already had been active in the theater at Bayreuth.

Such as activity and support from Jews was also succeeded Bayreuther Festspiel of Wagner. Parsifal got great success at first time by Jewish conductor Herman Levi (1839-1900).

On the other hand, in the times of Nazis called The Third Empire, it should be noticed that family member of Wagner insisted strongly to save Jewish supporter and musician in Bayreuther Festspiel from the view of their 
contribution of this Wagner's Festival in Bayreuth and their remarkable activity and profound understanding Arts of Wagner.

On the contrary, Nazis used this Arts of Wagner and this Festival altered Bayreuth as Holy place of National Socialism, German Superiority, with this Propaganda of Nazis, and invaded another country and persecuted beyond words against Jewish people so called Holocaust. In last chapter (conclusion) of this thesis, it is mentioned about these.

\subsection{Parsifal and Bayern King Ludwig II}

This chapter mentions new view of relationship among Parsifal and Bayern King Ludwig II (1845-86) who became patron of Wagner, using Legend of Holy Grail's Knight above mentioned.

The lineage of Ludwig II is House of Wittelsbach that was related to House of Andechs Meranien. It is said when he saw Wagner's Opera "Lohengrin" used Legend of Holy Grail's Knight above mentioned in youth, begin to become enthusiastic about Wagner's Opera Arts.

On the other hand, Wagner who aged reach to 50 years old in social and financial predicament also really felt himself "miracle" meeting of this young and attractive face and figure King like Parsifal as King of Holy Grail. When the envoy of Ludwig II came to invite Wagner, he thought "God's Miracle happened in real"(3th May 1864, letter to the king).

Ludwig II who promised support to Wagner began to build Castle of New swan (Schloss Neuschwanstein, 1869- ) imaging Wagner's Lohengrin as Holy Grail's Knight. This region with beautiful view of Mountains and Lakes around Schloss Neuschwanstein also had been closely influenced with House of Andechs Meranien.

Also Ludwig II who not only supported financially construction of Bayreuth Festspielhaus but also was highly interesting Parsifal of Wagner, and continued advice and financial support to Wagner to be completed this Opera.

The first idea of Parsifal was in 1857 above mentioned, when the first this draft completed in 1869, Ludwig II who sent Wagner his passionate eulogy that "This art (Parsifal) was divine, the most purely and highly-mind religion", promoted and demanded to complete as Opera.

This Ludwig II was popular among people in Bayern to raise art of culture in this area, but as called Märchen (Fantasy) King, was not so interesting real politics, was absorbed in Wagner's Opera World, such as Parsifal like King of Holy Grail surrounding youth guard with good looking like Holy Grail's Knights, lived in the nature of Bayern with blessing reach to Alps and his castles imaged Wagner's Opera World.

The his life was reminded life of above mentioned Markgraf G.Whilhelm reproduced at Bayreuth in $18^{\text {th }}$ century Legend of Holy Grail's Knight. It can say that Ludwig II in his later years also wanted to make Parsifal of Wagner completed in Land of Bayreuth, in short, put all his energy into reproduction of Legend of Holy Grail's Knight as same as Wagner.

After Wagner's death, Ludwig II who was isolated to be more apart from state affairs was also mysterious death confined by his attendants worried about future of state. His last place was Lake Starnberg where was birthplace of House of Andechs Meranien. This fact is only coincidence? Or, it was invited by this House Ludwig II who incarnated Parsifal as King of Holy Grail? At any rate, Ludwig II also finished his life into the Legend of Holy Grail's Knight as well as G.Whilhelm and Wagner.

However, Schloss Neuschwanstein that Ludwig II remained its beauty at that time saved from bombing and destruction of World War II, not ceased to stay this Castle even nowaday. Through of this "Holy Grail Castle" build in 19th century, it is possible to know about great influence of Parsifal as Legend of Holy Grail's Knight reproduced by Wagner in Bayreuth.

\section{Conclusion - Legend of Holy Grail's Knight and the significance in nowadays}

\subsection{From Bayreuth in Germany to the World of the Legend and Mysticism}

Ansbach in Germany where is said born place of W.Eschenbach is also closely to Bayreuth historically. This root also has origin of House of Andechs Meranien possessed both city at that time, after extinction of this House in the middle of $13^{\text {th }}$ century, both city continued to close contact keeping independent as city each other. For example, Bayreuth and Ansbach formed historically Personal Union in 3 times at total about One century $(1495 \sim 1515,1557 \sim 1603,1769 \sim$ 1791).

But in the latter half of $18^{\text {th }}$ century, land of Markgraf Bayreuth that merged with Markgraf Ansbach became Markgraf Ansbach-Bayreuth. Thus the Court of the Markgraf was moved from Bayretuh to Ansbach. Because of this loss 
of Markgraf's Court as central government and directly protection of the Markgraf, Bayreuth entered to declining time. And thus Bayreuth can not resist demanding the dispatching troops by England against Independent of America, in Bayreuth it was conscripted the reach to more than one thousand, was sent with troops of Ansbach to new continent of America.

The Bayreuth troop named "Dragon Regiments" with root of Markgraf G.Wilhelm Troop used to be known as brave his Knights with loyalty, stayed around New York where was main battle field of this War, over 5 years, fought against independent wing of America and this supporter of French army in sea and river and land.

After this war finished, it decided lose and to retreat of side of England troops, some of this troop such as Bayreuth in Germany remained and settled in this continent having new common ideal like Freemason close to Bayreuth tradition above mentioned.

This "frontier" in New continent, as for Bayreuth regiments, it can say that Sprit of House of Andechs Meranien in $12^{\text {th }}$ century that founded Bayreuth as new ideal land was piled up.

On the other hand, it was pointed out before that this ideal of Freemason was reflected in Parsifal of Wagner. However, in Legend of Holy Grail's Knight, it is nothing to be important of "secret" and "silence" like Freemazon.On this contrast, in Legend of Holy Grail's Knight, it is important of "talking" and "helping" such as "manner of helping each other through conversation to Mitleid(compassion)". This ideal was insisted very clearly in Parsifal of Wagner who was interesting formerly about Freemason.

Moreover, Legend of Holy Grail's Knight that is beyond ideal of Freemason as "friendship of the member of man" insists "real" cosmopolitanism by helping human to human reach to Elysium, have common value over time and foresight reach to nowadays called "society of earth and universe".

On the other hand, in time of completion of Parsifal and death of Wagner, it is said that he was strongly influenced in another theory. It is Buddhism such as life of Buddha, his theory of transmigration of souls, spiritual awakening, and deliverance.

Wagner who studied various religious theories in the world by books translated in German tried to make opera "the Winners" (1856) using life of Buddha in the same time of making Parsifal in middle of $19^{\text {th }}$ century.

The draft of scenario was made, but not completed. The essence of the Winners was put together in Parsifal gradually.

So, this Parsifal is strongly reflected ideology of affection in the nature and prohibition of hunting and fishing of animal. It must say that the final scene of Parsifal who overcome at last himself temptation and spiritual crisis is exactly final deliverance of Buddha. Winners".

Wagner put into Parsifal to the will of regeneration and transmigration under ideology of Buddhism drawn this "the

Message of Wagner in 1880 that put on Parsifal is "love - faith - : hope?" means relief and regeneration. In these meanings, Parsifal is exactly "hope" Festival opera sacred stage (Bühnenweihfestspiel) beyond ordinary stage opera like tragedy or comedy.

\subsection{Expansion and significance of Legend of Holy Grail's Knight -from opposition to cooperation}

After Legend of Holy Grail's Knight was appeared the incomplete original "Perceval" by C.Troyes in France, W.Eschenbach in German (the Holy Roman Empire) as the successor completed and renewed this Legend as Parzival in Era of "12th Century Renaissance".

And in the end of $19^{\text {th }}$ century, Wagner made it opera and visualized as Parsifal under his concept of comprehensive and synthetic art.

As these 3 persons called Trouvère, Minnesinger, and King of opera composer each other who had ability of making poetry and music at the same time, moreover the each person was great thinker as ideologist in their time and place too.

By these great composers, Legend of Holy Grail's Knight was taken over next generation. This Legend was researched and spread to the world by translation, had new and various analysis and interpretation gradually, and such as Mitleid(compassion) in nowadays beyond times.

At the stand of above viewpoints, the reason C.Troyes remained Perceval incomplete was clear that he looked after his Perceval's completion to next generation because that time was great change of history of the world, in short, superiority of Christian World that he stood himself was completely overturned.

Above mentioned, at first in Perceval, center of world was Europe and Christianity. And the next in Parzival, the center became the East and Islam and another religious country. 
And the last in Parsifal, the both (Perceval and Parzival) religious and national, regional character was abstracted and generalized, it is brought to sprit of relief through sympathy and helping as same human being beyond religion, nation, and region.

In Parsifal, the individuality who stood various opposing position such as wise and fool, social stronger and weaker, right way and sin, etc experienced in owns life time, sublimated everything such as deliverance, reach by the Mitleid to state like Heaven of God and Elysium. It can say that Parsifal achieved to evolve and change to universal Legend on common of human being to draw these processes.

Wagner experienced his life time with many trials and had many critics. But one of most hard and important his critic, E. Hanslick (1825-1904) also supported Wagner's Parsifal.

Even F.Nietzsche (1844-1900) who criticized that Wagner yielded to religion broke off relation of him, time of Wagner's death, As F.Nietzsche talked to stand in awe of Wagner's life and works, also It can say that Wagner in his later years set free "delusion" and "worldly desires".

It is also said that Wagner who settled in Bayreuth named new residence Wahnfried, in this entrance, Wagner wrote "In this land (Bayreuth), my delusion (Wahn) found free (fried).-Wahnfried- I(Wagner) named my new residence". This informs the state of new mind on Wagner's later years.

On the contrary, in the latter half of $19^{\text {th }}$ century Germany unified as nation at last. After Wagner's death, from about the beginning of the $20^{\text {th }}$ century, for the purpose of spreading in the territory, German fought with and invided to another countries.

In those situations, this Parsifal also was utilized maximally by Nazis to justify war of Germany as savoir of German nation or brave Hero fully defeating another enemy's country and different culture of enemy.

After the end of Second World War, everyone including Germany and another world country noticed and repented that these Nazis propaganda was entirely false and no countable tragedies such as Holocaust beyond words. And also, it looked like that Legend of Holy Grail's Knight utilized by Nazis buried into darkness of History, moreover Arts of Wagner and Bayreuth Festspiel was sealed forever.

However, the divided Germany after the war tried sincerely to "overcome the past" and revived the economy, was unified again as one independent nation while Germany keep to peace and cooperation policy in the world. Thus German history and Wagner Art was reconsidered the true value. Also Research of Legend of Holy Grail's Knight restarted gradually, for example, from original using historical approach and cross-culturing approach around the world. It can say exactly Parsifal story that starts again seeking "real" Holy Grail in long way beyond times.

\subsection{Legend of Holy Grail's Knight in now and Parsifal in Bayreuth}

In this century, Legend of Holy Grail's Knight is still alive. This new movement is seeking the Legend to another origin around the World. For example, about origin of Legend of Holy Grail as Wagner named Parsifal above mentioned, it is sought to Islamic World such as Arabia and Persia, moreover, Buddhism of Asian World, Animism of Africa, and believing God as Mother Earth in ancient world. In addition the view will expand and rise to highly common value, for example, equality of the sexes, respects for woman against patriarchy by man.

Such the Research of new interpretation to Legend of Holy Grail's Knight, after the end of World War, appeared direction of stage performance of Parsifal in-outside Germany. Especially, Bayreuth festspiele led and challenged this from various views seeking the new world of Parsifal.

Each researches and direction of Parsifal is very interesting around world beyond border, nation, and religion. These connects to Ideal of Bamberg and Bayreuth as "New Beirut" in $12^{\text {th }}$ century locating center of the Holy Roman Empire where House of Andechs Meranien sought as new place of Trade and Cultural exchange between the West and the East. Legend of Holy Grail's Knight also is succeeding in Bayreuth and each place of world in now through various historical dynamics.

In nowadays, keyword of Legend of Holy Grail's Knight is reminded first of all is "Mitleid (compassion)" that Wagner took over these works in $12^{\text {th }}$ century.

This story is because Persifal try to "ask" the King in despair like "I wanted to share your pain" with Mitleid, the King and everybody in the world come to relief by the grace of God, means spirituality of cooperation and helping as human being beyond social standing, circumstances, and gender.

In time of Crusader such as international religious battle and antagonism, the real peace that C.Troyes and W.Eschenbach sought at the time was took over by Wagner. This Legend of Holy Grail's Knight is the will as last words of them remained in future generation. There is entirely different with idol of Parsifal propagated by Nazis as national hero and savior, or superiority of Christianity against another religion above mentioned. 
On the another hand, in the modern international society after World War, antagonism between Christian world and Islamic world, because of problem reverting Holy place of Jerusalem and around city, it is seems like the era of Crusader. However, in time of the international religious war and serious tragedy, the real spirituality of Legend of Holy Grail's Knight that was born to change the world situation, above mentioned, gave up the antagonism, hostility and war, and built the ideal world of friendship, cooperation and peace under the Mitleid(compassion) as human being at 21st century in the World.

\section{Reference}

Csampai, A. u. Holland, D. (1984). Parsifal Texte,Materialien,Kommentare. Hamburg. Csampai \& Holland. (2002). Lohengrin. Texte, Materialien, Kommentare. Hamburg. Csampai \& Holland. (1986) Tannhäuser. Texte, Materialien, Kommentare. Hamburg. Wagner, R. (1986). Mein Leben Erster Band, Mein Leben Zweiter Band. Leipzig. Wagner, C. (1977). Die Tagebücher 1: 1869-1877, Die Tagebücher 2: 1878-1883. München. Westernhagen, C. (1979). Wagner. Zürich.

Chrétien de Troyes. (2009). Le Roman de Perceval ou Le Conte du Graal. Stuttgart.

Wolfram von Eschenbach. (2006). Parzival I, Parzival II. Frankfurt am Main.

Frappier, J. (1979). Chrétien de Troyes et Le Mythe du Graal. Paris.

Suneson, C. (1989). Richard Wagner und Die Indische Geisteswelt. Leiden.

Hennig, L. (1998). Die Andechs-Meranier in Franken. Europäisches Fürstentum im Hochmittelalter. Mainz.

Hamann, B. (2003). Winifred Wagner oder Hitlers Bayreuth. München.

Müssel, K. (1993). Bayreuth in acht Jahrhunderten: Geschichte der Stadt. Bindlach.

Trübsbach, R. (1993) . Geschichte der Stadt Bayreuth. Bayreuth.

Beyer, B. (1954). Gescichte der Grossloge Zur Sonne in Bayreuth Band 1 1741-1811, Band 2 1812-1900, Band 3 1901-1918. Frankfurt am Main.

Beckett, L. (1981). Richard Wagner: Parsifal. Cambridge

Kamata, Y. (2011). Parsifal - Mitleid in der neuzeitlichen Gesellschaft. Schopenhauers Philosophie der Musik.

Beiträge zur Philosophie Schopenhauers Band 10, Würzburg. S.185-201.

Kawanishi, T. (2011). Historical Studies about relationship between Legend of European Holy Grail's Knight and City of Bayreuth in Germany from "Pereval" to "Parzival", and "Parsifal". Studies in Comparative Culture (The Japan Association of Comparative Culture, No.99. pp. 25-46). Kyoto.

Kawanishi, T. (2009). Elysium drawn near to the traditional lake Bayreuth Markgraf Georg Wilhelm and Brandenburger See, Germany. Studies in Comparative Culture (The Japan Association of Comparative Culture, No.88. pp. 129-144). Kyoto.

Kawanishi, T. (2009). Historical research on Mysticism and Festival-tradition in Bayreuth Acculturation by Bayreuther Markgraf Georg Wilhelm, and his city of St.Georgen as Elysium, Germany. Studies in Comparative Culture(The Japan Association of Comparative Culture, No.89. pp. 35-53). Kyoto.

Kawanishi, T. (2008). Die Stadt Bayreuth und Richard Wagner. Germanistik Kyoto Nr.9 (Japanische Gesellschaft für Germanistik, Germanistenverband Kyoto) S.1-19, Kyoto 